1. MBBS, DPM, FCPS

Assistant Professor

Ghulam Muhammad MaharMedical

College, (GMC) Hospital Sukkur

2. Associate Professor

Department Of Psychiatry,

ShaheedMohtarma BenazirBhutto

Medical University,

Chandka Medical College Larkana.

3. MBBS, DPM,(MD Psychiatry)

Specialist Psychiatrist

Sir CowsjeeJehangir Institute of

Psychiatry (CJIP) Hyderabad.

4. PhD Psychiatry

Senior Lecturer

University Pendidkan

Sultan IdressTanjongMalim,

Pearl Malaysia

Corresponding Address:

Dr.InayatullahAwan

Postal Address: Dar ulShifa Heart

And Diabetic Clinic NearMashaAllah

Medical Centre Kandhkot.

inayatullahawan@gmail.com

Article received on:

03/04/2015

Accepted for publication:

07/05/2015

Received after proof reading:

09/09/2015

\section{SEVERE PSYCHIATRIC ILLNESSES; EFFECTIVENESS OF ILLNESS MANAGEMENT AND RECOVERY PROGRAM AS A GROUP INTERVENTION IN PATIENTS SUFFERING}

\section{Dr. Inayatullah Awan', Dr. Badaruddin Junejo², Dr. Jamil Junejo ${ }^{3}$, Dr.Asma Perveen ${ }^{4}$}

ABSTRACT...Objectives:To find out the effectiveness of "Illness management and Recovery (IMR)" program as a group intervention for improving daily functioning of clients suffering from severe psychiatric illnesses.Setting:The Recovery House, a Psychiatric Rehabilitation Center in Karachi, Pakistan. Period:Dec 2012 to Sep 2013.Methodology:Fifteen(15) patients were enrolled in the study. They were randomly divided into two groups, one group with 7 patients and the second with 8 patients. Informed consent was obtained from the patients and their family. A semi-structured Proforma was used to record the demographic details of patients. Before Starting the IMR program, 15 points rating scale was administered on patients (pre-IMR assessment) and after 9-month program implementation, the scale was again administered (post-IMR assessment) to evaluate the effectiveness of Illness management Program as a group intervention. After each IMR session patients received sheets to work as homework assignments from the handouts. Patients received IMR program with, supportive, educational, motivational and cognitive behavior interventions in group and individual sessions with practitioner. Data collected was entered into and analyzed by using statistical package for the social science seventeenth version (SPSS 17). Results:Out of the total 15 patients, 12 (80\%) were male and 3 $(20 \%)$ were female. Age range 15 to 67 years with mean age was $37+8.5$ years. Education status of the patients revealed that all patients were educated; $04(26.7 \%)$ had achieved education to the graduation level; 04 (26.7\%) were matriculate; 04 (26.7\%) were primary passed; and 03 (20\%) were educated up to intermediate level. Patients with severe psychiatric illnesses were bipolar disorder $2(13.3 \%)$ cases, personality disorder $3(20 \%)$ cases, delusional disorder $1(6.7)$ case, schizophrenia $8(53.3 \%)$ cases and schizoaffective $1(6.7 \%)$ cases. Total number of WMR (Wellness management and recovery) session attended by each patient ranged from 30 to 62 sessions. Results in 15 areas of assessment on the rating scale before the application of illness management and recovery sessions (Pre-IMR sessions) and after the application of sessions (Post-IMR sessions).Conclusion:Illness management and recovery program is an effective tool to bring about a significant improvement in several domains of life among patients suffering from severe psychiatric illnesses.

Key words: IMR illnes management and recovery, Depression, Delusional disorder

\section{INTRODUCTION}

Recovery of attitudes, values, feelings, goals, skills and roles in the process of being very subjective and unique. Recovery from illness mentally is recovering from an illness and illness despite the limitations imposed by living a satisfying, hopeful and productive can lead a person to live. ${ }^{1}$ Traditional medical definitions of recovery usually focus on remission/ resolution of symptoms and return to premorbid functioning. Although medical recovery from
Awan I, Junejo B, Junejo J, Perveen A. Severe psychiatric illnesses; effectiveness of illness management and recovery program as a group intervention in patients suffering. Professional Med J 2015;22(9):1170-1175. DOI: $10.17957 / T P M J / 15.2878$

severe psychiatric illnesses occurs ${ }^{2}$ alternative definitions have been forwarded which emphasize a combination of subjective aspects with improved functioning in various domains of life. ${ }^{3}$ People with psychiatric illnesses may have to recover from the social, psychological, and financial consequences including stigma attached to these illnesses; inevitable iatrogenic effects of treatment/medications; lack of recent opportunities for self-determination and unemployment; and the crushed dreams and 
future plans. ${ }^{4,5}$ In 1998, Lehman and Steinwachs a lot of attention last few years, schizophrenia and other serious mental illnesses, and improve the quality of service was to illustrate that it has become. This, coupled with that in the eyes of these methods are rarely provided to patients, research has been motivated by the standards of care for patients with schizophrenia on the basis of evidence. ${ }^{6}$

Despite the fact that new antipsychotic medications continue to be developed, persistent psychotic symptoms plague $25 \%-50 \%$ of patients with schizophrenia ${ }^{7,8}$, leading to a number of negative outcomes, including depression ${ }^{9,10}$ impaired social functioning, and low employment and productivity. More than $85 \%$ of persons with schizophrenia are unemployed, despite the fact that most want to work and are also capable of doing job. ${ }^{11,12}$

Illness management and recovery (IMR) program is an advanced and evidence-base psychiatric/ psychological strategy with good out come as a component of overall plan of management for patients suffering from severe mental illnesses. This program helps the patients to establish a collaboration with mental health professionals and cope appropriately with troublesome symptoms. ${ }^{13}$

Five empirically supported strategies / psychoemotional about the plan failed to protect the development of drugs daily routines, social cues, including a focus on strengthening the symptoms persisted and painful mental illness and its management, medication adherence, cognitivebehavior, described into the IMR program management, integration andsocial skills training, coping skills training. The curriculum Mini 9 divided the subjects. Weekly individual or group sessions need to be set up for about 9 months to complete. Patients, especially in others (eg, family, friends), self-management strategies for patients to learn and encouraged to play in helping to fulfill their own personal recovery goals. ${ }^{14}$

\section{MATERIAL AND METHODS}

The study was conducted at The Recovery House, A Psychiatric Rehabilitation Center in Karachi, Pakistan from Dec 2012 to Sep 2013. Fifteen(15) patients were enrolled in the study. They were randomly divided into two groups, one group with 7 patients and the second with 8 patients. Informed consent was obtained from the patients and their family. Patients and family were assured about the confidentiality of their personal record and information. A semi-structured Proforma was used to record the demographic details of patients. Before Starting the IMR program, 15 points rating scale was administered on patients (pre-IMR assessment) and after 9-month program implementation, the scale was again administered ((post-IMR assessment) to evaluate the effectiveness of Illness management Program as a group intervention. Group sessions (each 45 minutes) were conducted twice a week with both groups (4 session/ week). Weekly four family education sessions were carried out with the family of all patients. After each IMR session patients received sheets to work as home work assignments from the handouts. Patients received IMR program with, supportive, educational, motivational and cognitive behavior interventions in group and individual sessions with practitioner. Data collected was entered into and analyzed by using statistical package for the social science seventeenth version (SPSS 17).

\section{RESULT}

Out of the total 15 patients, 12 (80\%) were male and $3(20 \%)$ were female. Age range 15 to 67 years with mean age was $37 \pm 8.5$ years. Education status of the patients revealed that all patients were educated; 04 (26.7\%) had achieved education to the graduation level; 04 (26.7\%) were matriculate; 04 (26.7\%) were primary passed; and $03(20 \%)$ were educated up to intermediate level (Table-I). Patients with severe psychiatric illnesses were bipolar disorder 2(13.3\%) cases, personality disorder $3(20 \%)$ cases, delusional disorder 1(6.7) case, schizophrenia $8(53.3 \%)$ cases and schizoaffective $1(6.7 \%)$ cases. Total number of WMR (Wellness management and recovery) session attended by each patient ranged from 30 
to 62 sessions. Results in 15 areas of assessment on the rating scale before the application of illness management and recovery sessions (Pre-IMR sessions) and after the application of sessions

(Post-IMR sessions) are provided in table-II.

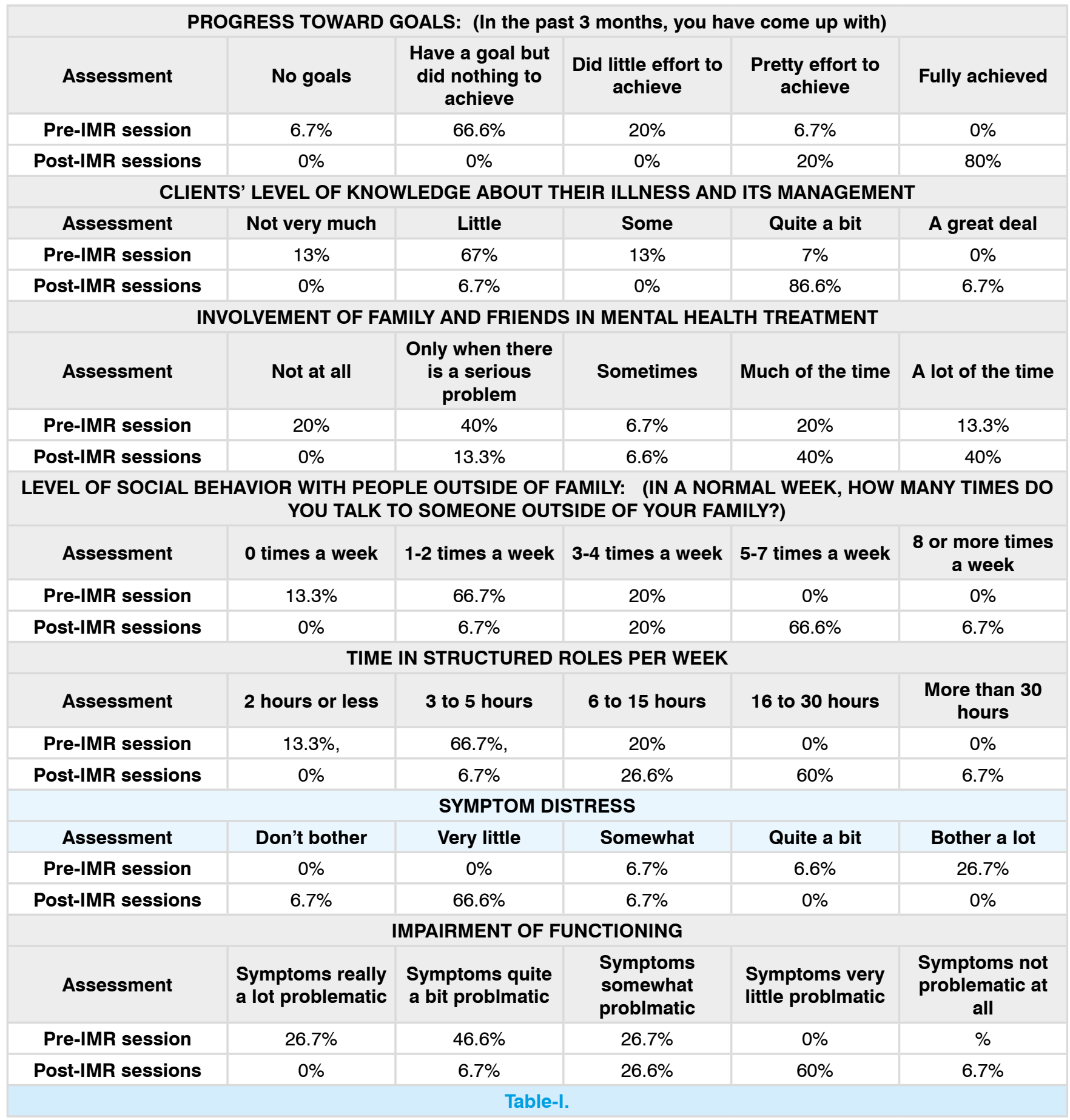


RELAPSE PREVENTION PLANNING

\begin{tabular}{|c|c|c|c|c|c|}
\hline Assessment & $\begin{array}{l}\text { Don't know } \\
\text { how to prevent } \\
\text { relapse }\end{array}$ & $\begin{array}{l}\text { Know a little, but } \\
\text { haven't made } \\
\text { any plan }\end{array}$ & $\begin{array}{l}\text { Know one or two } \\
\text { things but no } \\
\text { written plan }\end{array}$ & $\begin{array}{l}\text { Know several } \\
\text { things, but no } \\
\text { written plan }\end{array}$ & $\begin{array}{c}\text { Have a written } \\
\text { plan }\end{array}$ \\
\hline Pre-IMR session & $33.3 \%$ & $53.4 \%$ & $13.3 \%$ & $0 \%$ & $0 \%$ \\
\hline Post-IMR sessions & $0 \%$ & $26.7 \%$ & $66.6 \%$ & $6.7 \%$ & $0 \%$ \\
\hline \multicolumn{6}{|c|}{ RELAPSE OF SYMPTOMS } \\
\hline Assessment & $\begin{array}{l}\text { Within the last } \\
\text { month }\end{array}$ & $\begin{array}{c}\text { In the past } 2 \text { to } 3 \\
\text { months }\end{array}$ & $\begin{array}{l}\text { In the past } 4-6 \\
\text { months }\end{array}$ & $\begin{array}{l}\text { In the past } 7 \text { to } \\
12 \text { months }\end{array}$ & $\begin{array}{l}\text { No relapse in } \\
\text { the past year }\end{array}$ \\
\hline Pre-IMR session & $20 \%$ & $60 \%$ & $13.3 \% \%$ & $6.7 \%$ & $0 \%$ \\
\hline Post-IMR sessions & $0 \%$ & $0 \%$ & $33.3 \%$ & $66.7 \%$ & $0 \%$ \\
\hline \multicolumn{6}{|c|}{ PSYCHIATRIC HOSPITALIZATIONS } \\
\hline Assessment & $\begin{array}{l}\text { Within the last } \\
\text { month }\end{array}$ & $\begin{array}{c}\text { In the past } 2 \text { to } 3 \\
\text { months }\end{array}$ & $\begin{array}{l}\text { In the past 4-6 } \\
\text { months }\end{array}$ & $\begin{array}{l}\text { In the past } 7 \text { to } \\
12 \text { months }\end{array}$ & $\begin{array}{c}\text { No } \\
\text { hospitalization } \\
\text { in the past year }\end{array}$ \\
\hline Pre-IMR session & $53.3 \%$ & $20 \%$ & $6.7 \%$ & $20 \%$ & $0 \%$ \\
\hline Post-IMR sessions & $20 \%$ & $6.7 \%$ & $33.3 \%$ & $40 \%$ & $0 \%$ \\
\hline \multicolumn{6}{|c|}{ ABILITY OF COPING WITH MENTAL OR EMOTIONAL ILNESS } \\
\hline Assessment & Not well at all & Not very well & All right & Well & Very well \\
\hline Pre-IMR session & $20 \%$ & $60 \%$ & $20 \%$ & $0 \%$ & $0 \%$ \\
\hline Post-IMR sessions & $0 \%$ & $0 \%$ & $6.7 \%$ & $73.3 \%$ & $20 \%$ \\
\hline \multicolumn{6}{|c|}{ INVOLVEMENT WITH SELF-HELP ACTIVITIES } \\
\hline Assessment & $\begin{array}{l}\text { Don't know } \\
\text { about any self- } \\
\text { help activities }\end{array}$ & $\begin{array}{l}\text { Know about } \\
\text { some, but am } \\
\text { not interested }\end{array}$ & $\begin{array}{l}\text { Interested but } \\
\text { not participated } \\
\text { in the past year }\end{array}$ & $\begin{array}{c}\text { Participate } \\
\text { in self-help } \\
\text { activities } \\
\text { occasionally }\end{array}$ & $\begin{array}{c}\text { Participate } \\
\text { in self-help } \\
\text { activities } \\
\text { regularly }\end{array}$ \\
\hline Pre-IMR session & $6.7 \%$ & $33.3 \%$ & $20 \%$ & $33.3 \%$ & $6.7 \%$ \\
\hline Post-IMR sessions & $0 \%$ & $0 \%$ & $20 \%$ & $13.3 \%$ & $66.7 \%$ \\
\hline \multicolumn{6}{|c|}{ MEDICATION EFFECTIVELY } \\
\hline Assessment & Never & Occasionally & $\begin{array}{c}\text { About half the } \\
\text { time }\end{array}$ & Most of the time & Everyday \\
\hline Pre-IMR session & $0 \%$ & $6.7 \%$ & $0 \%$ & $13.3 \%$ & $80 \%$ \\
\hline Post-IMR sessions & $0 \%$ & $0 \%$ & $0 \%$ & $0 \%$ & $100 \%$ \\
\hline \multicolumn{6}{|c|}{ FUNCTIONING AFFECTED BY ALCOHOL USE } \\
\hline Assessment & $\begin{array}{c}\text { Functioning } \\
\text { affected quite } \\
\text { a bit }\end{array}$ & $\begin{array}{l}\text { Functioning } \\
\text { affected } \\
\text { somewhat }\end{array}$ & $\begin{array}{l}\text { Functioning } \\
\text { affected very } \\
\text { little }\end{array}$ & $\begin{array}{l}\text { not a factor in } \\
\text { my functioning }\end{array}$ & $\begin{array}{l}\text { Don't use } \\
\text { alcohol }\end{array}$ \\
\hline Pre-IMR session & $20 \%$ & 13.3\%, & $0 \%$ & $0 \%$ & $66.7 \%$ \\
\hline \multicolumn{6}{|c|}{ FUNCTIONING AFFECTED BY DRUG USE } \\
\hline Assessment & $\begin{array}{c}\text { Functioning } \\
\text { affected quite } \\
\text { a bit }\end{array}$ & $\begin{array}{l}\text { Functioning } \\
\text { affected } \\
\text { somewhat }\end{array}$ & $\begin{array}{l}\text { Functioning } \\
\text { affected very } \\
\text { little }\end{array}$ & $\begin{array}{l}\text { not a factor in } \\
\text { my functioning }\end{array}$ & $\begin{array}{c}\text { Don't have any } \\
\text { drug use }\end{array}$ \\
\hline Pre-IMR session & $13.3 \%$ & $20 \%$ & $0 \%$ & $0 \%$ & $66.7 \%$ \\
\hline Post-IMR sessions & $0 \%$ & $6.6 \%$ & $6.6 \%$ & $20 \%$ & $66.7 \%$ \\
\hline \multicolumn{6}{|c|}{ Table-II. } \\
\hline
\end{tabular}




\section{DISCUSSION}

This pilot study revealed that on pre-assessment sessions majority of the patients had an idea about their personal recovery goals but they did nothing to achieve that goal; no patient had achieved it fully. Administration of the IMR sessions had a dramatic impact which helped $80 \%$ of the patients to fully achieve a goal. Personal Recovery goals play an important role to build self-esteem, hope and a sense of being in control in clients suffering from severe mental illnesses. ${ }^{15}$

During IMR sessions patients set their own recovery goals for their recovery. Some patients set their goals activities such as: going for shopping, learning skills to visit bazaars, and money handling and talking with shop keepers. Others had their recovery goals to make friends and to achieve that end they learned social skills to interact with others and find people to talk with them in community, in parks and on social media. Some clients wanted to continue their education and started reading and writing with the support of their family and staff of the Recovery House and finally they were able to spend 4 to 5 hours for study. To do some job was another goal of few patients. As they had working experience before the onset of their illness and were educated as well, so they were able to find supportive employment with help of their family. Within groups they learned the strategies to handle stress related issues and social skills which could be helpful for them at their workplace.

The evaluation showed that most of clients had little or no knowledge about their illness and its management before the administration of IMR sessions. Since Illness management and Recovery program's main focus is on education about illness and its management ${ }^{13}$, so its application brought a significant a change among the patients in their understanding about their illness and its management.

Illness management and Recovery program brought a positive change among patients in their belief about the involvement of family and other important people in the treatment. Such a positive change can be helpful in the compliance and cooperation of patients and hence better management of their illness. ${ }^{15}$

Patients in our study showed a significant improvement in social relations on post-IMR assessment contrary to view of Bellack (2004) who explored that improvement in the quality of social relationships and social support may simply take longer to be achieved. For example, skills training programs usually report changes in social functioning and behavior in schizophrenia patients over 1-2 years. Thus the relatively small amount of time devoted in the IMR program to improving social behavior is insufficient to make a viable impact on social relationships. ${ }^{16,17}$

\section{CONCLUSIONS}

This study has shown that Illness management and recovery program is an effective tool to bring about a significant improvement in several domains of life among patients suffering from severe psychiatric illnesses. Fifteen domains were studied including understanding and knowledge about their illness, progress toward recovery goals, level of social behavior with people outside of family, time spent in structured roles, distress related to symptoms, impairment of functioning and others.

\section{Copyright@ 07 May, 2015.}

\section{REFERENCES}

1. Anthony, WA: Recovery from mental illness: the guiding vision of the mental health service system in the 1990's. Psychosocial Rehabilitation Journal, 1993, 16(4), 11-23.

2. Ciompi $L$. The natural history of schizophrenia in the long term. Br J Psychiatry. 1980;136:413-420.

3. Ridgway PAE. The Recovery Papers. Vol 1. Lawrence, KS:University of Kansas School of Social Welfare; 2000.

4. Mead S, Copeland ME. What recovery means to us: consumers' perspectives. Community Ment Health J. 2000;36: 315-328.

5. Roe D, Chopra M. Beyond coping with mental illness: toward personal growth. Am J Orthopsychiatry. 2003;73: 334-344.

6. Lehman AF, and Steinwachs DM. (1998) Patterns of 
usual care for schizophrenia: initial results from the schizophrenia Patient Outcomes Research Team (PORT) client survey. Schizophrenia Bulletin 1998.; 2411-20.

7. Curson DA, Patel M, Liddle PF, Barnes TRE. Psychiatric morbidity of a long stay hospital population with chronic schizophrenia and implications for future community care. BMJ. 1988;297:819-822.

8. Kane JM. Treatment resistant schizophrenic patients. J Clin Psychiatry. 1996;57(suppl 9):35-40).

9. Birchwood M, Mason R, MacMillian F, Healy J. Depression,demoralization and control over psychotic illness: a comparison and non-depressed patients with a chronic psychosis.Psychol Med. 1993;23:387-395.

10. Mueser KT, Douglas MS, Bellack AS, Morrison RL. Assessment of enduring deficit and negative symptom subtypes in schizophrenia. Schizophr Bull. 1991;17:565-582.

11. Marwaha S, Johnson S. Schizophrenia and employment: a review. SocPsychiatr Psychiatr
Epidemiol. 2004;39:337-49.

12. McQuilken M, Zahniser JH, Novak J, Starks RD, Olmos A, Bond GR. The work project survey: consumer perspectives on work. J VocatRehabil. 2003;18:59-68.

13. Mueser $T$ K, Corrigan $P$ W, Hilton D W, Tanzman B, Schaub A, Gingerich $S$ et al. Illness Management and Recovery: A Review of the Research. Psychiatric Services. 2002;53: 1272-84.

14. Drake RE, Goldman HH, Leff HS, Lehman AF, Dixon $\mathrm{L}$, Mueser KT, et al. Implementing evidence-based practices in routine mental health service settings. Psychiatr Serv. $2001 ; 52: 179-82$.

15. Russinova Z. Providers' hope-inspiring competence as a factor for optimizing rehabilitation outcomes. $J$ Rehab 1999; 65(4):50-57.

16. Medication non-compliance [internet] [accessed on 0101-2015], available from http:/www.schizophrenia.com.

17. Bellack AS. Skills training for people with severe mental illness. Psych Rehab J. 2004;27:375-91..

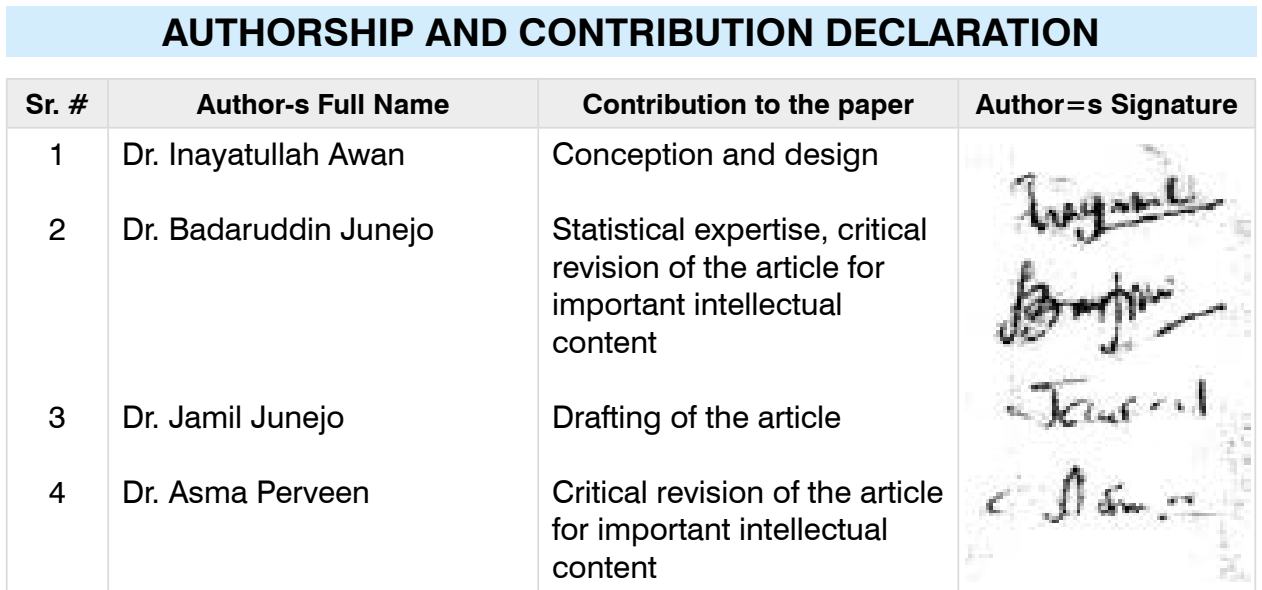

